\title{
Agro techniques in orchids
}

\section{Introduction}

The flowering plants satisfy man's requirement for food, shelter, clothing, drugs besides adding to his aesthetic values. Their latter utility accounts for a high lucrative international trade in floriculture. Plants worth US \$ 100 billion were traded last year and the trade is expected to cross $\$ 600$ billion mark by the turn of the century. Till very recently, the trade primarily revolved around roses, lilies, carnations, chrysanthemums, tulips etc. but the trend is now fast shifting in favour of orchids, for their long lasting flowers of myriad shapes, sizes and colors (Figures 1-4).

The orchids (family Orchidaceae) represent a diverse group of young plants, still in evolutionary flux. The orchids are popular with the professionals \& hobbyists for their highly fascinating and beautiful flowers which are bestowed with long lasting properties. The orchid cultivation is fast emerging as an absorbing \& rewarding vocation besides being an admirable antidote to the otherwise busy routine of life.

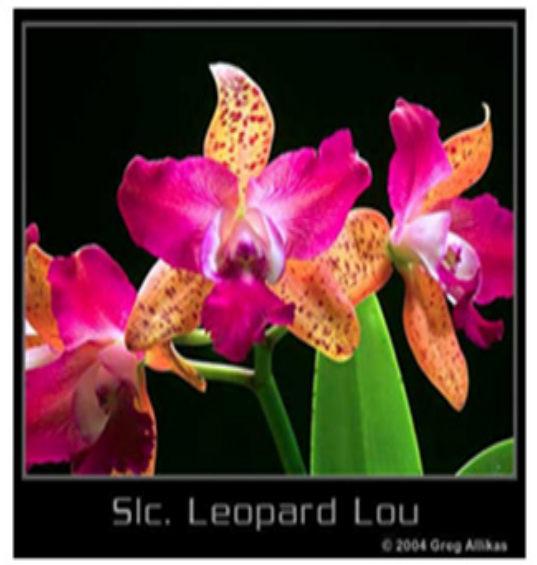

Figure I Laeliocattleya.

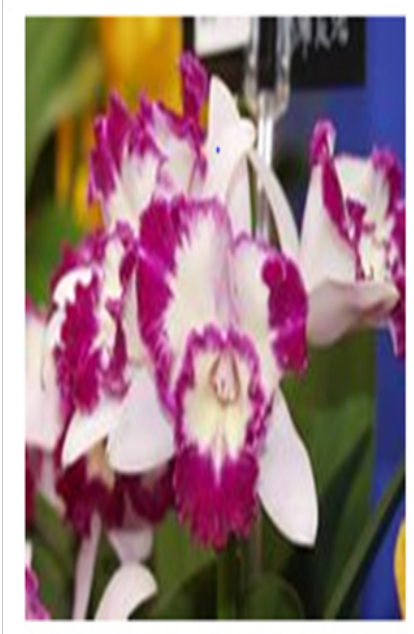

Figure 2 Cattleya.
Volume 2 Issue I - 2017

\section{Vishal Sharma}

Department of Botany, Post Graduate College for Girls, India

Correspondence: Vishal Sharma, Associate Professor, Department of Botany, Post Graduate College for Girls - I I, Chandigarh, India, Email VISHAL_2370@yahoo.com

Received: December 04, 2016 | Published: January 31, 2017

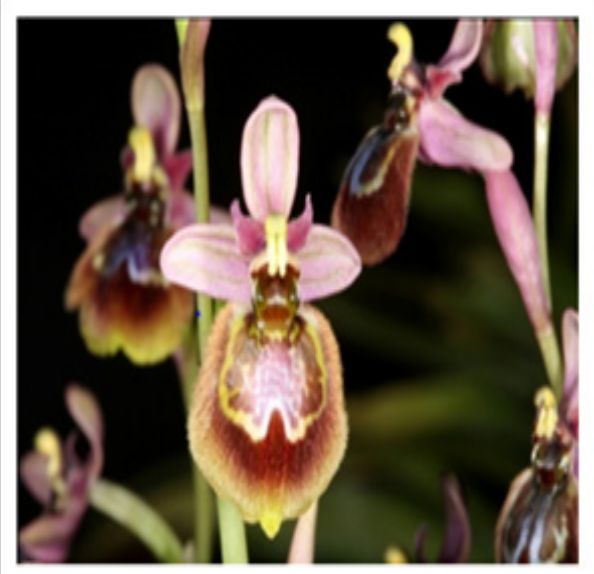

Figure 3 Ophrys

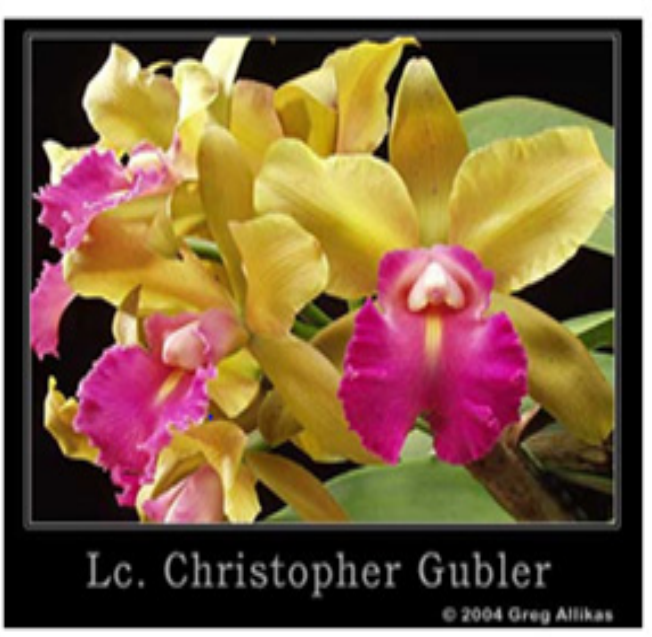

Figure 4 Laeliocattleya.

The orchid cultivation generated great impetus when Joseph Arditti et al. ${ }^{1}$ made an interesting observation that the average life span of people associated with orchids is generally longer (7213.8 years) 
than the general average, the latter seems more plausible because of curative and aphrodisiac properties of these plants (Table 1).

Table I Orchids and their therapeutic uses

\begin{tabular}{|c|c|c|}
\hline Acampe anthropophora & $\mathrm{R}$ & Anti malarial \\
\hline Acampe papillosa & $\mathrm{R}$ & In rheumatism \\
\hline Aerides odoratum & $\mathrm{R}$ & Anti-tuberculosis \\
\hline Ceologyne henri & Ps & To treat tuberculosis \\
\hline C. ovalis & Ps & As an aphrodisiac \\
\hline $\begin{array}{l}\text { Cirrhopetalum } \\
\text { maculosum }\end{array}$ & $\mathrm{R}$ & To enhance longevity \\
\hline $\begin{array}{l}\text { Corallorhiza } \\
\text { odontorhiza }\end{array}$ & $\mathrm{R}$ & To treat malignancy \\
\hline Cypripedium elegans & $\mathrm{R}$ & To treat nervous disorders \\
\hline C. maculosum & $\mathrm{R}$ & To promote longevity \\
\hline C. pubescence & $\mathrm{R}$ & To treat nervous disorders \\
\hline Dactylorhiza hatageria & $\mathrm{R}$ & As expectorant and astringent \\
\hline $\begin{array}{l}\text { Ephermerantha } \\
\text { fimbriata }\end{array}$ & $\mathrm{L}$ & As an aphrodisiac \\
\hline Eria muscicola & Ps & $\begin{array}{l}\text { To treat cardiac, respiratory and } \\
\text { nervous disorders }\end{array}$ \\
\hline Eulophia campestris & $\mathrm{T}$ & $\begin{array}{l}\text { As an aphrodisiac and to treat } \\
\text { cardiac problems }\end{array}$ \\
\hline E. dabia & $\mathrm{T}$ & $\begin{array}{l}\text { As an aphrodisiac and blood } \\
\text { purifier }\end{array}$ \\
\hline E. nuda & $\mathrm{T}$ & To treat tumors and bronchitis \\
\hline Goodyera pubescence & $\mathrm{L}$ & $\begin{array}{l}\text { To treat malignant ulcers and } \\
\text { rattle-snake bites }\end{array}$ \\
\hline Habenaria viridis & $\mathrm{R}$ & As an aphrodisiac \\
\hline Liparis odorata & Ps & To treat malignant ulcers \\
\hline Lissochilus beravensis & Ps & To treat nervous disorders \\
\hline Microstylis wallichii & Ps & $\begin{array}{l}\text { As an aphrodisiac, nerve tonic \& } \\
\text { enhances sperm formation }\end{array}$ \\
\hline Rhynchostylis retusa & S & To treat rheumatism \\
\hline Satyrium nepalense & $\mathrm{R}$ & To treat malaria and dysentery \\
\hline Vanda cristata & $\mathrm{L}$ & As expectorant \\
\hline Vanda roxburgii & $\mathrm{L}$ & $\begin{array}{l}\text { In rheumatism, ear infections and } \\
\text { fractures }\end{array}$ \\
\hline Vanda testacea & $S, R$ & $\begin{array}{l}\text { To treat rheumatism, nervous } \\
\text { disorder, and scorpion stings }\end{array}$ \\
\hline
\end{tabular}

L, leaf; Ps, pseudo bulb; R, root; S, shoot; T, tuber

Besides these, Habenaria edgeworthi, H. intermedia, Malaxis muscifera, Ephemerantha macrai, are important ingredients of a rejuvenating drug "Chyawanprash". Hence, orchid growing has emerged as an admirable hobby and in order to make this hobby as more enjoyable and meaningful, the following information may be useful.

\section{Potting}

Orchids are usually potted during spring, occasionally young plants may occasionally be potted during autumn as well. However, they need to be repotted every alternate year. Earthen pots, plastic containers and hanging baskets (wooden) can be used for the purpose. Moss, pine bark, brick, clay and charcoal pieces can be effectively used as better potting material for almost any kind of epiphytic orchid (Table 2). Coconut fibre, however, retains moisture longer than other of these materials. Crocking (pieces of broken clay pots) or polystyrene packing chips can be put in the bottom of the pots to enhance drainage. Adequate ventilation helps control bacteria and fungi. However, air movement without proper humidity will desiccate the plants and cause damage. To control humidity in summer, use gravel trays. Put gravel into trays and fill it with water. Place pots in these trays.

Table 2 Potting material for some epiphytic orchids

\begin{tabular}{llll}
\hline $\begin{array}{l}\text { S } \\
\text { No. }\end{array}$ & $\begin{array}{l}\text { Species/ } \\
\text { hybrids }\end{array}$ & $\begin{array}{l}\text { Commercial } \\
\text { biological } \\
\text { significance }\end{array}$ & $\begin{array}{l}\text { Potting mixture } \\
\text { (moss, pine bark, } \\
\text { clay pots, brick \& } \\
\text { charcoal pieces) }\end{array}$ \\
\hline 1 & Cattleya & Ornamental & 2:4:1:1:1 \\
2 & Cymbidiump & Ornamental & 1:2:2:1:1 \\
3 & $\begin{array}{l}\text { Rhynchostylis } \\
\text { retusa }\end{array}$ & $\begin{array}{l}\text { Ornamental } \\
\text { medicinal }\end{array}$ & I:I:1:1:1 \\
4 & Vanda & Ornamental & 1:2:1:1:2 \\
5 & Dendrobium & Ornamental & 1:2:2:1:2 \\
\hline
\end{tabular}

During potting, the plants may be correctly positioned using metallic, wooden, bamboo, or plastic stakes. The plants can even be hanged on wooden rats or mango logs but then they would require frequent watering. The dead tissue/organs, if any, may be removed with the help of sterilized tools. The terrestrial orchids require sandy and organic soil as a potting material. The $\mathrm{pH}$ of the soil is, however, important as it influences the absorption of the nutrients, a $\mathrm{pH}$ ranging between $4.5-5.0$ yields best result.

\section{Watering}

Watering is important thing to get right in orchid growing. Most orchids are epiphytic, they grow on trunk of other plants, and obtain moisture from the air. There really is no hard rule for watering that can be applied across all orchids, but in general, watch out crinkled leaves and shrinked pseudo bulbs are signs that more water is needed. A rule of thumb, if unsure about whether to give water or not, is simple to abstain from giving water .Too much water is worse than somewhat too little. A good technique of watering is to scoop up water with the pot and let the water flow through the potting material.

\section{Air and moisture}

In nature, orchids grow hanging upside- down from tree-stems and branches. The much better air circulation and humidity are important factors controlling growth of orchids. Most plants do best with humidity in the range of $60 \%$ to $80 \%$, but the average home register about $30 \%$ to $40 \%$. In your home you can increase or raise the humidity level somewhat, in a few different ways eg. spray with spray bottle on plant parts or by putting the plants in an orchidarium. The circulation of air is very important in orchidariums. Smaller fans can be used to get the air in movement and your plants respond with more vigorous growth. 


\section{Temperature}

Most in-home temperature are acceptable for growing the most common types of Orchids. Cattleya, Cymbidium, Paphiopedilum, Oncidium etc can also be grown with great success under normal home temperatures. The difference between night and day temperatures can be substantial in nature. To imitate the difference, a decrease in temperature by 5-10c during nights, can be applied. Generally, production of flowers is 'started' or induced by a temperature fluctuating period. The microclimate is very important to recognize when trying to imitate mother nature.

\section{Light}

Light is probably the single most crucial factor in determining whether or not your plants will bloom. The appropriate amount of light is necessary for proper plant growth. Place your plants close to windows in east side. Southern windows tend to let in too much heat from the sun. Orchids shouldn't be put in unprotected sunlight as they might burn. If the leaves become very yellow \& dark spots appear, move the plant to a shadier location.

\section{Flowering}

Like in other plants, the flowering in orchids is directly correlated with hereditary and or environmental (temperature, light, chemical stimulus). That the environmental factors play an important role in inducing flower is more than exemplified in orchids since a majority of them fail to flower in homes other than natural ones. However, the recent possibilities that the flowering can be regulated under controlled conditions ${ }^{2}$ have added new dimensions to orchid floriculture. Some such possibilities are being tested for the benefit of orchid enthusiasts.

A. A combination of red \& blue light favours optimal growth and flowering in orchids.

B. A correct ratio between the light and dark periods initiates the production of phytochrome, long night is more important in bringing about flowering than the short day in short day plants and vice versa.

C. Since the flower production increases sharply with the decrease in the endogenous level of auxins in plants, a spray of anti auxins proves useful for inducing flowering. Moreover as direct sunlight is inversely correlated with auxin level in the shoot apex the flowering intensity can be controlled by manipulating the exposure of the plants to direct sunlight.

D. Night temperature plays an important role in flowering i.e. night temperature of $55-60^{\circ} \mathrm{F}$ will favour flowering while that of $65^{\circ} \mathrm{F}$ might suppress flowering.

E. A fortnightly treatment of NPK (12:32:16) induces enlarged flowers and extra long inflorescence.

F. Exogenous supply of gibberellins induce and enhance flowering in many orchid species. Spray of Gibberellins $(1 \mathrm{mg} / \mathrm{l})$ weekly preponed the flowering.

\section{Propagation}

Orchids can be propagated by both seeds and vegetative means. It is difficult for a common grower to raise plants from seeds which requires good amount of experience \& knowledge, hence they rely on multiplication by traditional method of vegetative propagation such as by division, cutting, air layering etc. Though easier to follow, these are slow processes and only few plants can be multiplied from one plant in a year.

\section{Division}

The method involved in dividing large clumps into smaller units can be adopted satisfactorily for orchids belonging to sympodial group. This method of propagation is suitable for genera like Cattleya, Laelia Cymbidium, Dendrobium, Ceologyne, Epidendrum etc. It was, however, suggested not to divide the plants unless these were 8-12 pseudo bulbs of large size. Rather than carrying out the division process immediately, preliminary cut should be made one or two months before actual division of the specimen. The bigger the size of the plant, the better will be re-establishment after separation.

\section{Off shoots or keikis}

Orchids with long cane-like stems as Dendrobium and Epidendrum, produce little plants with roots at the nodal region of their pseudo bulbs or stem. Off shoots are also produced in Phaius and Phalaenopsis. Present study indicate that application of cytokinins induced off shoots or Keikis in Dendrobium (Figure 5) These Keikis can be separated from the parent plant and set in small pots containing mixture recommended for mother plant (Figure 6) (Figure 7).

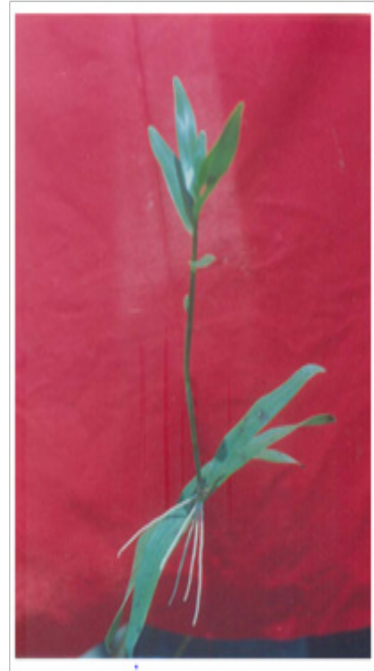

Figure 5 Application of cytokinins induced off shoots or Keikis in Dendrobium.

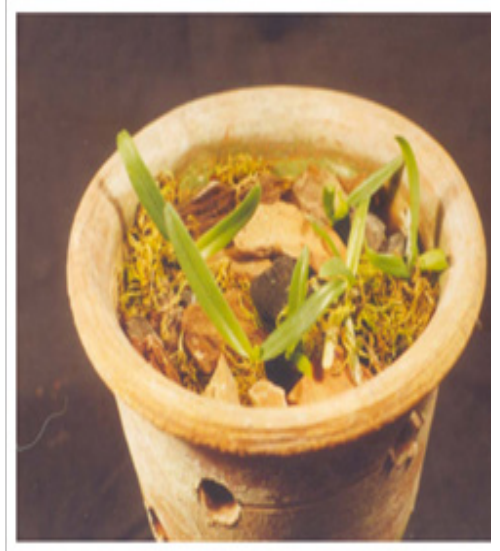

Figure 6 These Keikis can be separated from the parent plant and set in smal pots containing mixture recommended for mother plant 


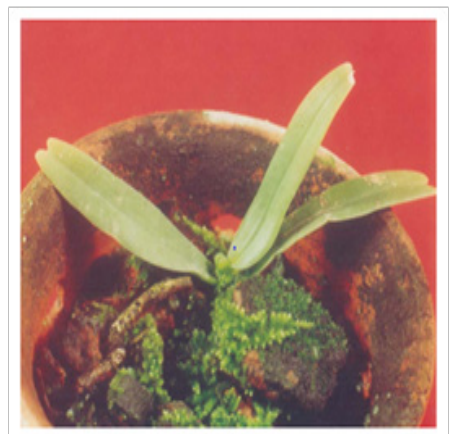

Figure 7 These Keikis can be separated from the parent plant and set in small pots containing mixture recommended for mother plant.

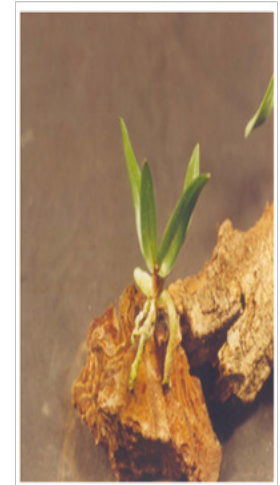

Figure 8 When the root formation is completed the layer is removed from the mother plant and planted on bark piece.

\section{Cuttings}

Monopodial species are difficult to propagate vegetatively. Cuttings, preferably with a few roots, are sometimes successful with Vanda, Renanthera, Arachnis, Phalaenopsis etc. Stems should nearly be cut in sections of 3-4 nodes and placed in moist sand or damp Sphagnum moss, kept in a cool and dry place, for root formation.

\section{Air layering}

Vanda and some other monopodial orchids may also be propagated by air layering. The method was to give a slant cut partially through the stem, $20-30 \mathrm{~cm}$ below the apex and wrap with Sphagnum moss or Osmunda fibre around the cut portion. When the root formation is completed the layer is removed from the mother plant and planted on bark piece (Figure 8) and later in pot having potting mixture used for growing the mother plant.

\section{Repotting}

Repotting is only necessary when the body of the plant has grown over the pot edge or the media itself breakdown. Shrewd bark, Sphagnum moss and coconut fibres are commonly used in orchid media. It's important that there can be a circulation of air through the pot. The plant must not be let standing wet for longer periods of time. The best time to repot is at the begin of the growing season. This gives the plant the best chance to grow into the new pot and secure itself.

Follow these basic steps to re-pot your orchid:

A. Gently remove media from roots giving warm water washings in the in vitro plantlets.

B. Gently ease the plant out of its old pot from in vivo grown plants. Don't be afraid to destroy the old pot if it helps in keeping the roots intact. Remove dried or brown roots. Put drainage material in the bottom of the pot.

C. Place the plant in the pot. Cover the pot with polythene and make holes in polythene at intervals to decrease humidity. Water lightly until the plants adjusts to its new pot.

D. Spray fungicides (Bavistin;0.1\%) at fortnight interval and observe the plants regularly for leaf spots if any.

\section{Acknowledgements}

None.

\section{Conflict of interest}

The author declares no conflict of interest.

\section{References}

1. Arditti A, Ernst R. Micropropagation of Orchids. New Jersey, USA; John Wiley, sons; $1993.696 \mathrm{p}$.

2. Lawler LJ. Ethanobotany of the Orchidaceae-A Manual. In: Orchid Biology: Reviews and Prespectives. Ithaca, USA: Cornell University Press; 1984. p. 27-149. 